\title{
AGRAVO DE INSTRUMENTO E TAXATIVIDADE MITIGADA: ANÁLISE DOS PRESSUPOSTOS DA RECORRIBILIDADE EXCEPCIONAL DE DECISÕES INTERLOCUTÓRIAS IMPREVISTAS ${ }^{1}$
}

\section{INTERLOCUTORY APPEAL AND MITIGATED TAXATIVENESS: ANALYSIS OF THE ASSUMPTIONS OF THE EXCEPTIONAL RECORRECTABILITY OF UNFORESEEN INTERLOCUTORY DECISIONS}

Rodrigo Martins Cantanhede Pós-graduando em Direito Processual Civil pela Universidade do Estado do Rio de Janeiro (UERJ). Bacharel em Direito pela Universidade Federal do Maranhão (UFMA). Advogado (OAB-MA). Imperatriz/MA. E-mail: rodrigo.cantanhede@hotmail.com.

Fernanda Arruda Léda Leite Zenkner Doutoranda em Direitos Humanos pela Universidade Federal de Goiás (UFG). Mestra em Direito e Instituições do Sistema de Justiça pela Universidade Federal do Maranhão (UFMA). Bacharela em Direito pela Universidade Federal do Maranhão (UFMA). Professora na Unidade de Ensino Superior do Sul do Maranhão (Unisulma) e na Universidade Ceuma. Advogada (OAB-MA). Imperatriz/MA. E-mail: fernandaarrudaledal@gmail.com.

RESUMO: Com base no Tema Repetitivo 988 do STJ, esta análise pretendeu identificar e caracterizar os elementos do enunciado da tese jurídica fixada e da fundamentação do voto da Rela. Mina. Nancy Andrighi que justificam o agravamento atípico de decisões interlocutórias imprevistas. O método científico utilizado foi a abordagem dedutiva, e as técnicas de investigação empregadas foram a bibliográfica e a documental. Como principal

\footnotetext{
${ }^{1}$ Artigo recebido em 05/11/2020 e aprovado em 05/04/2021.
} 
inferência alcançada, tem-se que três requisitos orientam a recorribilidade excepcional de pronunciamentos incidentais por agravo de instrumento: urgência, inutilidade do julgamento da questão no recurso de apelação e inadmissão prospectiva da repetição de atos processuais.

PALAVRAS-CHAVE: Agravo de instrumento. Decisões interlocutórias imprevistas. Recorribilidade excepcional. Taxatividade mitigada. Urgência.

ABSTRACT: On the basis of the Repetitive Theme 988 of the STJ, this analysis was intended to identify and characterize the elements of the statement of the legal thesis set and the grounds of rapporteur's vote Ministrer Nancy Andrighi who justify the atypical aggravation of unforeseen interlocutory decisions. The scientific method used was the deductive approach, and the research techniques employed were bibliographic and documentary. As the main inference achieved, it is found that three requirements guide the exceptional recorrectability of incidental pronouncements by interlocutory appeal: urgency, uselessness of judging the issue in the appeal and prospective inadmissibility of the repetition of procedural acts.

KEYWORDS: Interlocutory appeal. Unforeseen interlocutory decisions. Exceptional recorrectability. Mitigated taxativeness. Urgency.

\section{INTRODUÇÃ̃}

Instituído pela Lei n. 13.105/2015, o Código de Processo Civil vigente inaugurou um novo sistema processual, pois trouxe ao ordenamento jurídico brasileiro mais do que um compilado de alterações legislativas procedimentais. Sua comparação com o antecessor Código de Processo Civil de 1973 permite constatar que houve distinta estruturação do recurso designado à impugnação imediata de decisões interlocutórias, o qual recebeu a denominação singular de agravo de instrumento.

A atual configuração do recurso impõe como regra a recorribilidade limitada de pronunciamentos incidentais, uma vez que, pela leitura dos dispositivos do estatuto 
processual, somente as hipóteses indicadas expressamente pelo legislador podem ser combatidas de imediato, em separado, incluídas as eventuais situações previstas em leis extravagantes. Na prática, entretanto, essa nova tentativa de perfeita sistematização também não foi satisfatória. Percebeu-se tanto na doutrina como na jurisprudência que outras questões deveriam ter sido igualmente enxergadas com especial atenção.

Finalmente, após afetação dos REsp n. 1.696.396/MT e 1.704.520/MT para julgamento pelo rito dos recursos especiais repetitivos, a Corte Especial do Superior Tribunal de Justiça (STJ) definiu que a aparente taxatividade da relação de interlocutórias agraváveis pode sofrer atenuação a depender do caso.

Desse modo, com o intuito de aprofundar a discussão sobre essa importante decisão, a questão que se põe em análise neste estudo é: quais são os requisitos para a interposição do agravo de instrumento contra decisões interlocutórias imprevistas ${ }^{2}$ ? Por meio de raciocínio dedutivo e das técnicas de investigação bibliográfica e documental (já que se explorará os acórdãos paradigmas dos recursos especiais), o objetivo estabelecido é identificar e caracterizar os elementos do enunciado da tese jurídica fixada e da fundamentação do voto da Rela. Mina. Nancy Andrighi que justificam a recorribilidade de decisões interlocutórias imprevistas por agravo de instrumento.

A insegurança jurídica que decorre da incompreensão do posicionamento construído consiste na principal justificativa da presente pesquisa, uma vez que, se a avaliação das decisões interlocutórias imprevistas não for sistematizada, perpetuar-se-á o agravamento de considerável quantidade delas a pretexto de que a interpretação jurisprudencial alcança as matérias que lhes correspondem. No momento atual, há uma necessidade pendente de melhor esclarecimento do entendimento firmado pelo STJ.

\section{IMPUGNAÇÃO DAS DECISÕES INTERLOCUTÓRIAS NO SISTEMA PROCESSUAL VIGENTE}

A exposição de motivos do CPC de 2015 descreve que um dos objetivos principais da comissão de juristas era a simplificação de subsistemas, como o recursal, mas

2 O termo "imprevisto" e suas variações serão empregados para definir as decisões interlocutórias não expressas no art. 1.015 do CPC. 
ressalva que essa finalidade "em momento algum significou restrição ao direito de defesa. Em vez disso deu [...] maior rendimento a cada processo individualmente considerado"3, o que poderia ser demonstrado pela instituição do agravo de instrumento como meio único de impugnação de apenas algumas decisões interlocutórias.

Os demais pronunciamentos incidentais devem ser suscitados preliminarmente em apelação ou nas respectivas contrarrazões ${ }^{4}$, o que remete ao antigo agravo retido na perspectiva de que "a matéria da decisão interlocutória pode ser rediscutida em momento superveniente" ". Uma diferença é que o agravo retido devia ser interposto imediatamente para evitar a preclusão, ao passo que, na atual sistemática, a recorribilidade das interlocutórias não agraváveis é diferida. Consequentemente, não se perde a faculdade processual de impugná-las enquanto não surge o momento oportuno.

A mesma regra não é válida, porém, para as hipóteses de cabimento previstas no art. 1.015 do $\mathrm{CPC}^{6}$, pois o $\S 1^{\circ}$ do art. 1.009 regula somente aquelas não recorríveis em

3 BRASIL. Código de processo civil e normas correlatas. 7. ed. Brasília: Senado Federal: Coordenação de Edições Técnicas, 2015. p. 33.

4 De acordo com o $\S 1^{\circ}$ do art. 1.009 do CPC, "as questões resolvidas na fase de conhecimento, se a decisão a seu respeito não comportar agravo de instrumento, não são cobertas pela preclusão e devem ser suscitadas em preliminar de apelação, eventualmente interposta contra a decisão final, ou nas contrarrazões" (BRASIL. Lei $n^{\circ} 13.105$, de 16 de março de 2015. Código de processo civil. Brasília: Presidência da República, 2015. Disponível em: http://www.planalto.gov.br/ccivil_03/_ato20152018/2015/lei/113105.htm. Acesso em: 21 jul. 2019).

5 LEMOS, Vinicius Silva. O agravo de instrumento e evolução no direito brasileiro. In: COSTA, Eduardo José da Fonseca et al. (coord.). História do processo. São Paulo: ABDPRO: Editora Exegese, 2018. p. 503-544. p. 534. Com isso, "nota-se que o legislador fez clara opção por maior celeridade processual na fase de conhecimento, postergando o eventual reexame de questões processuais para análise conjunta quando do julgamento da apelação, desde que a parte interessada expressamente devolva essas matérias ao conhecimento do tribunal" (MARANHÃO, Clayton. Observações sobre o rol taxativo das hipóteses de cabimento do recurso de agravo de instrumento no $\mathrm{CPC} / 2015$, na perspectiva da duração razoável do processo. In: CARVALHO FILHO, Antônio; SAMPAIO JUNIOR, Herval (org.). Os juízes e o novo CPC. Salvador: Editora JusPodivm, 2017. p. 337-356. p. 341).

6 “Art. 1.015. Cabe agravo de instrumento contra as decisões interlocutórias que versarem sobre: I - tutelas provisórias; II - mérito do processo; III - rejeição da alegação de convenção de arbitragem; IV - incidente de desconsideração da personalidade jurídica; V - rejeição do pedido de gratuidade da justiça ou acolhimento do pedido de sua revogação; VI - exibição ou posse de documento ou coisa; VII - exclusão de litisconsorte; VIII - rejeição do pedido de limitação do litisconsórcio; IX - admissão ou inadmissão de intervenção de terceiros; $X$ - concessão, modificação ou revogação do efeito suspensivo aos embargos à execução; XI - redistribuição do ônus da prova nos termos do art. 373, § 1º XII - (VETADO); XIII outros casos expressamente referidos em lei. Parágrafo único. Também caberá agravo de instrumento contra decisões interlocutórias proferidas na fase de liquidação de sentença ou de cumprimento de sentença, no processo de execução e no processo de inventário" (BRASIL. Lei n 13.105, de 16 de março de 2015. Código de processo civil. Brasília: Presidência da República, 2015. Disponível em: http://www.planalto.gov.br/ccivil_03/_ato2015-2018/2015/lei/113105.htm. Acesso em: 21 jul. 2019). 
separado $^{7}$. Aliás, "o legislador [...] optou por enumerar as hipóteses de cabimento do recurso em detrimento da expressão aberta empregada pela codificação de 1973: lesão grave e de difícil reparação" ${ }^{n}$. Assim, restabeleceu a configuração do Código de Processo Civil de 1939.

As interlocutórias agraváveis no CPC de 2015 são as indicadas no art. 1.015 e ao longo do estatuto. O inciso XIII desse dispositivo admite a ampliação das hipóteses de cabimento, mas, para Daniel Amorim Assumpção Neves ${ }^{9}$, apesar da referida possibilidade, a relação de decisões recorríveis por agravo é restrita. Rodrigo Frantz Becker ${ }^{10}$ corrobora ao explicar que "isso não retira a taxatividade do rol de cabimento do recurso, na medida em que não se confere poder discricionário ao magistrado para verificar, diante de conceitos vagos, se é o caso ou não de decisão agravável”.

O CPC de 2015 especificou, portanto, onze matérias agraváveis, autorizou a ampliação das hipóteses de cabimento no inciso XIII do art. 1.015 e trouxe no parágrafo único deste dispositivo regra ampla que não provoca tanta perplexidade, já que possibilita a impugnação de todas as decisões incidentais às fases processuais de liquidação e cumprimento de sentença e aos processos de execução e inventário, sem necessidade de análise minuciosa.

\subsection{Controvérsia acerca da natureza jurídica do rol de cabimento do agravo}

A princípio, a aparente taxatividade foi considerada vantajosa, visto que "a análise histórica também mostrou que [...] o grande número de hipóteses de cabimento do agravo

7 Sobre o sistema de preclusão, arrematam Fredie Didier Jr. e Leonardo Carneiro da Cunha: "Na fase de conhecimento, as decisões agraváveis sujeitam-se à preclusão, caso não se interponha o recurso. Aquelas não agraváveis, por sua vez, não se sujeitam à imediata preclusão. Não é, todavia, correto dizer que elas não precluem. Elas são impugnadas na apelação (ou nas contrarrazões de apelação), sob pena de preclusão" (Curso de direito processual civil: meios de impugnação às decisões judiciais e processo nos tribunais. 13. ed. Salvador: Editora JusPodivm, 2016. p. 205).

8 LUCON, Paulo Henrique dos Santos. Evolução do agravo no sistema jurídico brasileiro: das ordenações lusitanas ao novo código de processo civil. In: SILVA, José Anchieta da (org.). O novo processo civil. São Paulo: Lex Magister Editora, 2012. p. 591-655. p. 637, grifo do autor.

9 Manual de direito processual civil. 9. ed. Salvador: Editora JusPodivm, 2017.

10 O rol taxativo (?) das hipóteses de cabimento do agravo de instrumento. Publicações da Escola da AGU, Brasília, v. 9, n. 4, p. 237-252, out./dez. 2017. Disponível em: https://seer.agu.gov.br/index.php/EAGU/article/view/2020/1745. Acesso em: 21 mar. 2020. p. 240. 
de instrumento impedia um estudo organizado do assunto" $"$. Contudo, algumas matérias imprevistas também passaram a exigir reapreciação imediata, o que motivou o surgimento de controvérsia sobre a real natureza jurídica do rol de decisões agraváveis.

Uma das posições era a de que a enumeração legal seria taxativa em grau absoluto, razão pela qual as hipóteses de cabimento deveriam ser analisadas por uma perspectiva impreterivelmente restritiva. $\mathrm{Na}$ jurisprudência, esse entendimento foi sustentado no REsp n. 1.700.308/PB.

Entre os fundamentos apresentados pelos defensores dessa visão, estava o de que os recorrentes não poderiam ser prejudicados pela preclusão por acreditarem que nenhuma outra questão exigiria reexame imediato e, assim, aguardassem para recorrer no momento oportuno. De acordo com Rodrigo Frantz Becker ${ }^{12}$, onde havia possibilidade, o legislador autorizou expressamente a realização de interpretações expansivas, o que já não fez em relação ao recurso em questão.

Outro grupo também reconhecia a taxatividade da relação de cabimento do agravo, mas admitia certa flexibilização por meio de interpretação extensiva ou analógica. Alexandre Freitas Câmara ${ }^{13}$ contestou a literalidade estrita do art. 1.015 do CPC e compreendeu que o rol fechado não obstaria a aplicação dos referidos métodos a algumas hipóteses com termos mais genéricos.

Cassio Scarpinella Bueno ${ }^{14}$ concordou com a "interpretação ampliativa das hipóteses do art. 1.015, sempre conservando, contudo, a razão de ser de cada uma [...] para não generalizá-las indevidamente", e Luiz Guilherme Marinoni, Sérgio Cruz Arenhart e Daniel Mitidiero ${ }^{15}$ afirmaram que a indicação limitada de decisões agraváveis não impediria interpretação por analogia, que pode contribuir para a atribuição de sentido às normas. Na jurisprudência, esse pensamento foi adotado no REsp n. 1.679.909/RS.

11 GONZALEZ, Gabriel Araújo. A recorribilidade das decisões interlocutórias no código de processo civil de 2015. 2016. Dissertação (Mestrado em Direito) - Faculdade de Direito, Universidade Federal da Bahia, Salvador, 2016. Disponível em: https://repositorio.ufba.br/ri/bitstream/ri/19980/1/Gabriel\%20Ara\%C3\%BAjo\%20Gonzalez\%20\%20A\%20recorribilidade\%20das\%20decis\%C3\%B5es\%20interlocut\%C3\%B3rias\%20no\%20CPC\%202 015.pdf. Acesso em: 23 jun. 2019. p. 233.

12 O rol taxativo (?) das hipóteses de cabimento do agravo de instrumento. Publicações da Escola da AGU, Brasília, v. 9, n. 4, p. 237-252, out./dez. 2017. Disponível em: https://seer.agu.gov.br/index.php/EAGU/article/view/2020/1745. Acesso em: 21 mar. 2020.

13 O novo processo civil brasileiro. São Paulo: Editora Atlas, 2015.

14 Novo código de processo civil anotado. São Paulo: Saraiva, 2015. p. 653.

15 Novo código de processo civil comentado. 3. ed. São Paulo: Editora Revista dos Tribunais, 2017. 
Já a concepção da terceira vertente era a de que o rol legal seria meramente exemplificativo. Com isso, ainda que determinada decisão interlocutória não estivesse entre as indicadas no art. 1.015 do CPC ou não pudesse ser alcançada por interpretações expansivas, seria impugnável por agravo de instrumento se exigisse reapreciação imediata.

Essa é a visão apresentada por José Rogério Cruz e Tucci ${ }^{16}$, para quem a análise de matérias de ordem pública passíveis de provocar nulidade absoluta do processo não pode ser postergada para a ocasião do julgamento da apelação. $\mathrm{O}$ autor chegou a defender a suavização da literalidade da norma, a fim de que se pudesse interpor agravo mesmo na falta de autorização legal expressa.

William Santos Ferreira ${ }^{17}$ sustenta que, diante de possível dano irreparável ou de difícil reparação, não há razão em facultar unicamente a interposição de apelação, sob pena de afronta aos princípios da inafastabilidade do controle jurisdicional e da razoável duração do processo. Para o autor, nem sequer seria alternativa adequada o mandado de segurança, em consequência de sua incompatibilidade com a sistemática da recorribilidade imediata. Por isso, há a vertente implícita da "recorribilidade imediata necessária por inutilidade prospectiva"18 ${ }^{18}$, porquanto a taxatividade do rol de cabimento do agravo é frágil.

\section{RECURSOS ESPECIAIS REPRESENTATIVOS DA CONTROVÉRSIA NO SUPERIOR TRIBUNAL DE JUSTIÇA}

A competência do STJ para julgar recursos especiais é verificada em três situações, duas das quais fundamentaram a interposição dos REsp n. 1.696.396/MT e 1.704.520/MT, a saber, divergência da decisão recorrida com lei federal e atribuição de interpretação diferente da que outro tribunal houver dado à lei federal (art. 105, III, "a" e "c", da CF, respectivamente).

16 Ampliação do cabimento do recurso de agravo de instrumento. Revista Consultor Jurídico, São Paulo, 18 jul. 2017. Coluna Paradoxo da Corte. Disponível em: https://www.conjur.com.br/2017-jul-18/paradoxocorte-ampliacao-cabimento-recurso-deagravo-instrumento. Acesso em: 23 mar. 2020.

17 Cabimento do agravo de instrumento e a ótica prospectiva da utilidade - o direito ao interesse na recorribilidade de decisões interlocutórias. Revista de Processo, São Paulo, ano 42, v. 263, p. 193-203, jan. 2017.

18 FERREIRA, William Santos. Cabimento do agravo de instrumento e a ótica prospectiva da utilidade - o direito ao interesse na recorribilidade de decisões interlocutórias. Revista de Processo, São Paulo, ano 42, v. 263, p. 193-203, jan. 2017. p. 200, grifo do autor. 
A competência do juízo era a principal matéria em ambos os recursos especiais, razão pela qual se acredita que tal questão tenha sido o impulso das maiores discussões sobre o art. 1.015 do CPC, embora já se houvesse constatado a ausência de outras hipóteses de cabimento do recurso no rol legal. Apesar da omissão do legislador em indicá-la entre as decisões interlocutórias recorríveis de imediato, a necessidade de seu reexame instantâneo passou a ser sentida na prática, porquanto era notório o prejuízo que poderia resultar do processamento de determinada demanda em juízo incompetente.

Em consideração à controvérsia suscitada, o STJ afetou os recursos especiais mencionados para julgamento pelo rito dos recursos especiais repetitivos, sob relatoria da Mina. Nancy Andrighi. A matéria submetida à apreciação foi classificada como Tema 988 e, ao invés de se restringir apenas à competência, foi ampliada para qualquer situação não expressa na relação do art. 1.015 do CPC.

\subsection{Interpretação do art. 1.015 do CPC e pressupostos da recorribilidade excepcional}

O exame preliminar da natureza jurídica da relação contida no art. 1.015 do CPC teve como base a constitucionalização do processo civil, fenômeno expresso no art. $1^{\circ}$ do código $^{19}$. Referido dispositivo compõe o conjunto de normas processuais civis fundamentais e subordina toda a matéria à observância dos valores e das normas constitucionais. Assim, afirmou-se que a regra ditada pelo art. 1.015 "não é - e nem pode ser interpretada como - uma ilha oceânica, isolada e distanciada de seu sistema jurídico" ${ }^{20}$.

Inicialmente, reconheceu-se que o agravo de instrumento teve o uso restringido por conveniência legislativa, ou seja, a limitação foi realmente intencionada, em

19 "O processo civil será ordenado, disciplinado e interpretado conforme os valores e as normas fundamentais estabelecidos na Constituição da República Federativa do Brasil, observando-se as disposições deste Código" (BRASIL. Lei $n^{\circ} 13.105$, de 16 de março de 2015. Código de processo civil. Brasília: Presidência da República, 2015. Disponível em: http://www.planalto.gov.br/ccivil_03/_ato20152018/2015/lei/113105.htm. Acesso em: 21 jul. 2019).

20 BRASIL. Superior Tribunal de Justiça. Recurso Especial $n^{\circ} 1.696 .396$ - MT (2017/0226287-4). Recurso especial representativo de controvérsia. Direito processual civil. Natureza jurídica do rol do art. 1.015 do CPC/2015. [...]. Relatora: Mina. Nancy Andrighi, 5 de dezembro de 2018. Disponível em: https://ww2.stj.jus.br/websecstj/cgi/revista/REJ.cgi/ITA?seq=1731780\&tipo=0\&nreg=201702262874\&S eqCgrmaSessao $=\&$ CodOrgaoJgdr $=\& d t=20181219 \&$ formato=PDF\&salvar=false. Acesso em: 22 jun. 2019. p. 37. 
detrimento da premissa jurídica básica de que a lei é incapaz de regulamentar a realidade de maneira ampla e completa, argumento este exposto nos acórdãos como princípio da flexibilização da taxatividade ${ }^{21}$.

Tal conclusão é o ponto de partida para a compreensão da recorribilidade de decisões interlocutórias imprevistas por agravo, uma vez que é impossível reduzir situações a um conjunto fechado. Mais factível é estabelecer condições genéricas à interposição do recurso contra diferentes hipóteses não indicadas no rol legal ${ }^{22}$, ou seja, é preciso aperfeiçoar um padrão ao qual se adequem outros casos em vez de tentar antevêlos. Exatamente por isso se assentou que o cabimento do agravo contra decisões não expressas no art. 1.015 do CPC sempre será determinado pela urgência.

Defende-se que referido elemento é o que justifica a própria existência dessa via de impugnação, embora algumas das matérias escolhidas pelo legislador não reclamem reexame imediato. Se não fosse a emergência de solução exigida por determinadas questões, nem sequer existiria motivo para a criação de recurso destinado a combater interlocutórias antes da decisão definitiva da causa.

Ademais, identificou-se que o pressuposto da urgência decorre da "inutilidade do julgamento diferido se a impugnação for ofertada apenas conjuntamente ao recurso contra o mérito, ao final do processo"23.

Essa constatação está associada ao princípio constitucional da inafastabilidade do controle jurisdicional, que deixou de ser enxergado unicamente pela ótica do ingresso em

21 "O estudo da história do direito também revela que um rol que pretende ser taxativo raramente enuncia todas as hipóteses vinculadas a sua razão de existir, pois a realidade normalmente supera a ficção e a concretude torna letra morta o exercício de abstração inicialmente realizado pelo legislador" (BRASIL. Superior Tribunal de Justiça. Recurso Especial $n^{o}$ 1.696.396 - MT (2017/0226287-4). Recurso especial representativo de controvérsia. Direito processual civil. Natureza jurídica do rol do art. 1.015 do CPC/2015. [...]. Relatora: Mina. Nancy Andrighi, 5 de dezembro de 2018. Disponível em: https://ww2.stj.jus.br/websecstj/cgi/revista/REJ.cgi/ITA?seq=1731780\&tipo=0\&nreg=201702262874\&S eqCgrmaSessao $=\&$ CodOrgaoJgdr $=\& d t=20181219 \&$ formato=PDF\&salvar=false. Acesso em: 22 jun. 2019. p. 39).

22 PUGLIESE, William Soares. REsp 1704520/MT - uma análise da decisão sobre o rol taxativo mitigado do agravo de instrumento. Revista Jurídica da Escola Superior de Advocacia da OAB-PR, Curitiba, ano 4, n. 1, p. 305-325, maio 2019. Disponível em: http://revistajuridica.esa.oabpr.org.br/wpcontent/uploads/2019/05/revista-esa-cap-12.pdf. Acesso em: 15 abr. 2020.

23 BRASIL. Superior Tribunal de Justiça. Recurso Especial no 1.696.396 - MT (2017/0226287-4). Recurso especial representativo de controvérsia. Direito processual civil. Natureza jurídica do rol do art. 1.015 do CPC/2015. [...]. Relatora: Mina. Nancy Andrighi, 5 de dezembro de 2018. Disponível em: https://ww2.stj.jus.br/websecstj/cgi/revista/REJ.cgi/ITA?seq=1731780\&tipo=0\&nreg=201702262874\&S eqCgrmaSessao $=\&$ CodOrgaoJgdr $=\& d t=20181219 \&$ formato $=P D F \&$ salvar $=$ false. Acesso em: 22 jun. 2019. p. 41. 
juízo para ser compreendido também sob a acepção do direito de recorrer oportunamente. De acordo com a Ministra Relatora, é “inconcebível, a partir do princípio da inafastabilidade da jurisdição, que apenas algumas poucas hipóteses taxativamente arroladas pelo legislador sejam objeto de imediato enfrentamento" 24 .

Outro fundamento apresentado é o de que o processo é meio utilizado para a solução adequada de litígios em marcha progressiva, ou seja, "não pode e não deve ser um instrumento de retrocesso na pacificação dos conflitos" ${ }^{25}$. Com isso, se a reforma da decisão em segunda instância oferece risco de anulação do feito e de repetição dos atos processuais em primeiro grau, deve-se admitir a recorribilidade imediata da matéria. Conforme mencionado nos acórdãos, há uma relação também entre esse último fundamento e a citada urgência.

Depois de examinada a matéria submetida à apreciação do STJ, a Corte Especial formulou a seguinte tese jurídica: "O rol do art. 1.015 do CPC é de taxatividade mitigada, por isso admite a interposição de agravo de instrumento quando verificada a urgência decorrente da inutilidade do julgamento da questão no recurso de apelação"26. Tal enunciado demonstra a real natureza jurídica do rol de decisões agraváveis, a qual difere das demais projeções que haviam sido formuladas na doutrina e na jurisprudência.

\section{PERSPECTIVAS SOBRE A TAXATIVIDADE MitigadA E POSSÍVEL INTERPRETAÇ̃̃O DA TESE JURÍDICA}

24 BRASIL. Superior Tribunal de Justiça. Recurso Especial $n^{\circ} 1.696 .396$ - MT (2017/0226287-4). Recurso especial representativo de controvérsia. Direito processual civil. Natureza jurídica do rol do art. 1.015 do CPC/2015. [...]. Relatora: Mina. Nancy Andrighi, 5 de dezembro de 2018. Disponível em: https://ww2.stj.jus.br/websecstj/cgi/revista/REJ.cgi/ITA?seq=1731780\&tipo=0\&nreg=201702262874\&S eqCgrmaSessao $=\&$ CodOrgaoJgdr $=\& d t=20181219 \&$ formato=PDF\&salvar=false. Acesso em: 22 jun. 2019. p. 43.

25 BRASIL. Superior Tribunal de Justiça. Recurso Especial no 1.696.396 - MT (2017/0226287-4). Recurso especial representativo de controvérsia. Direito processual civil. Natureza jurídica do rol do art. 1.015 do CPC/2015. [...]. Relatora: Mina. Nancy Andrighi, 5 de dezembro de 2018. Disponível em: https://ww2.stj.jus.br/websecstj/cgi/revista/REJ.cgi/ITA?seq=1731780\&tipo=0\&nreg=201702262874\&S eqCgrmaSessao $=\&$ CodOrgaoJgdr $=\& d t=20181219 \&$ formato=PDF\&salvar $=$ false. Acesso em: 22 jun. 2019. p. 44.

26 BRASIL. Superior Tribunal de Justiça. Recurso Especial $n^{\circ} 1.696 .396$ - MT (2017/0226287-4). Recurso especial representativo de controvérsia. Direito processual civil. Natureza jurídica do rol do art. 1.015 do CPC/2015. [...]. Relatora: Mina. Nancy Andrighi, 5 de dezembro de 2018. Disponível em: https://ww2.stj.jus.br/websecstj/cgi/revista/REJ.cgi/ITA?seq=1731780\&tipo=0\&nreg=201702262874\&S eqCgrmaSessao $=\&$ CodOrgaoJgdr $=\& d t=20181219 \&$ formato=PDF\&salvar=false. Acesso em: 22 jun. 2019. p. 58, grifo do autor. 
A análise feita nos acórdãos dos recursos especiais afetados evidenciou a insustentabilidade das três posições que tentaram definir a natureza jurídica do rol de decisões agraváveis. De acordo com a Ministra Relatora, nenhuma delas seria suficiente para alcançar todas as possíveis hipóteses de cabimento que, por um inequívoco propósito de restrição, deixaram de ser incluídas pelo legislador no art. 1.015 do CPC.

Segundo William Soares Pugliese ${ }^{27}$, a fundamentação do entendimento é completa e coerente, de modo que a compreensão extraída contém um significado mais amplo do que a acepção proveniente da terminologia taxatividade mitigada, criada como mera expressão designativa. O autor esclarece que os incisos do art. 1.015 do CPC não devem ser flexibilizados, mas é possível interpor agravo de instrumento também em outras situações que exigirem reapreciação imediata pelo tribunal ${ }^{28}$.

Em comentário ao art. 1.015 do CPC, Cláudio Antônio Soares Levada ${ }^{29}$ faz referência à posição firmada pela Corte Especial do STJ e a considera harmônica com as exigências da realidade prática. Afirma que a decisão corrigiu o erro no qual o legislador de 2015 incorreu quando intentou prever todos os casos que demandariam urgência na reanálise em virtude da gravidade do pronunciamento judicial proferido, pois "não há agilidade ou celeridade processuais que possam prevalecer diante da possibilidade concreta de danos irreversíveis ou de grande onerosidade (evitável) às partes"30.

27 REsp 1704520/MT - uma análise da decisão sobre o rol taxativo mitigado do agravo de instrumento. Revista Jurídica da Escola Superior de Advocacia da OAB-PR, Curitiba, ano 4, n. 1, p. 305-325, maio 2019. Disponível em: http://revistajuridica.esa.oabpr.org.br/wp-content/uploads/2019/05/revista-esa-cap12.pdf. Acesso em: 15 abr. 2020.

28 Carolina Uzeda considera que "não há mitigação, uma vez que a taxatividade seguirá sendo respeitada. Há, em realidade, o acolhimento normativo de uma situação latente, percebida pela prática e que, até então, havia sido ignorada pelo legislador. Há tutela adequada da situação de urgência, em âmbito recursal, tal qual determina a Constituição" (O STJ e a taxatividade mitigada do art. 1.015 do CPC. In: FONSÊCA, Vitor. Diário processual, [s. 1.], 10 dez. 2018. Disponível em: https://diarioprocessual.com/2018/12/10/a-taxatividade-mitigada-do-art-1-015-do-cpc-segundo-o-stj/. Acesso em: 25 jul. 2020).

29 Breves anotações sobre os três anos de vigência do CPC/2015. Revista de Direito Processual Civil, Jundiaí, v. 1, n. 1, p. 6-9, jan./jun. 2019. Disponível em: http://www.portal.anchieta.br/revistas-elivros/direito-processual-civil/pdf/artigo-direito-proc-civil-vol1-1.pdf. Acesso em: 17 abr. 2020.

30 LEVADA, Cláudio Antônio Soares. Breves anotações sobre os três anos de vigência do CPC/2015. Revista de Direito Processual Civil, Jundiaí, v. 1, n. 1, p. 6-9, jan./jun. 2019. Disponível em: http://www.portal.anchieta.br/revistas-e-livros/direito-processual-civil/pdf/artigo-direito-proc-civil-vol11.pdf. Acesso em: 17 abr. 2020. p. 8. 
Para Fernanda Pagotto Gomes Pitta ${ }^{31}$, entretanto, a visão sustentada pela Ministra Relatora, em vez de pacificar a intensa discussão, ocasionaria o surgimento de novas dúvidas, estas sobre o que é ou não urgente. A autora ainda argumenta que a análise de cada uma das hipóteses de cabimento imprevistas pode ser perniciosa, diante da possibilidade de variadas interpretações serem provocadas ${ }^{32}$.

Carlos Augusto de Assis ${ }^{33}$ acompanha o "entendimento de que permanece a insegurança jurídica relativa ao tema. Durante um bom tempo iremos discutir, caso a caso, se naquela situação os pressupostos constantes da tese firmada estão presentes".

Contudo, até as hipóteses de cabimento indicadas originariamente pelo legislador estão sujeitas a constantes rediscussões, de modo que não há consenso absoluto tampouco sobre o que está, em princípio, bem-regulamentado. Confirma esse raciocínio a frequente elaboração de enunciados doutrinários ${ }^{34}$ que interpretam os incisos do art. 1.015 do CPC e tratam da possibilidade de agravamento de determinadas decisões interlocutórias não necessariamente explícitas no rol legal.

“Ao afirmar estar mitigando o rol do art. 1.015, o STJ está, na realidade,

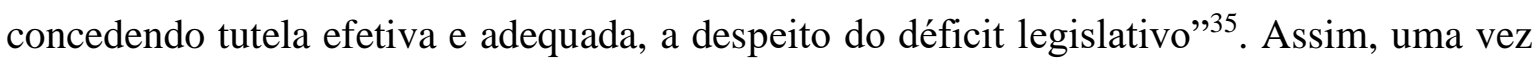
que a grande preocupação percebida corresponde às divergências interpretativas que

31 Cabimento do agravo de instrumento no novo código de processo civil: as decisões agraváveis de instrumento. 2019. Dissertação (Mestrado em Direito) - Pontifícia Universidade Católica de São Paulo, São Paulo, 2019. Disponível em: https://tede2.pucsp.br/bitstream/handle/22172/2/Fernanda\%20Pagotto\%20Gomes\%20Pitta.pdf. Acesso em: 1 jul. 2019.

32 No mesmo sentido é a conclusão obtida por José Galbio Oliveira Junior: "Enfrentando os problemas decorrentes das más escolhas legislativas, o STJ apresentou solução igualmente ruim, substituindo a perplexidade da ausência de hipóteses absolutamente relevantes não previstas como hipótese de recorribilidade imediata, pela perplexidade de uma tese que não entrega uma regra clara de cabimento do recurso, de modo que as partes possam prever com segurança se será admitido ou não, fazendo ressurgir o critério do código revogado" (Agravo de instrumento: panorama atual da natureza jurídica do rol do art. 1.015 do código de processo civil. Revista Eletrônica Organizações e Sociedade, Iturama, v. 8, n. 9, p. 140-149, jan.jun. $2019 . \quad$ Disponível em: http://revista.facfama.edu.br/index.php/ROS/article/download/430/347. Acesso em: 11 maio 2020. p. 148-149).

33 Agravo de instrumento: um olhar para o passado, uma reflexão sobre o nosso futuro. Revista Brasileira de Direito Processual - RBDPro, Belo Horizonte, ano 27, n. 106, p. 145-159, abr./jun. 2019. p. 154.

34 São exemplos os enunciados 29, 103, 154, 177, 435, 560, 611, 612, 693 e 706 do Fórum Permanente de Processualistas Civis (FPPC), os enunciados 69, 70, 71, 72 e 93 da I Jornada de Direito Processual Civil e o enunciado 145 da II Jornada de Direito Processual Civil.

35 UZEDA, Carolina. O STJ e a taxatividade mitigada do art. 1.015 do CPC. In: FONSÊCA, Vitor. Diário processual, [s. 1.], 10 dez. 2018. Disponível em: https://diarioprocessual.com/2018/12/10/a-taxatividademitigada-do-art-1-015-do-cpc-segundo-o-stj/. Acesso em: 25 jul. 2020. 
podem ser ocasionadas principalmente pelo termo urgência, propor-se-á uma leitura não somente do citado vocábulo, mas também dos demais fundamentos apresentados pela Ministra Relatora nos acórdãos dos recursos especiais repetitivos para justificar a relativização da sistemática do agravo de instrumento.

Inicialmente, serão analisados dois elementos essenciais verificados já no enunciado da tese jurídica do STJ, quais sejam, a mencionada urgência e a expressão inutilidade do julgamento da questão no recurso de apelação.

\subsection{O que é urgência?}

Normalmente, quem quer que bata à porta do Poder Judiciário almeja a satisfação ou a provisão tão célere quanto possível da pretensão entregue. É comum o autor de uma ação judicial considerar que, por mais simples que seja sua demanda, deva esta ser apreciada e solucionada pelo juiz sem demora, sob pena de lhe sobrevir prejuízo maior do que a lesão ou a ameaça que houver motivado o ajuizamento da causa.

Além disso, nem sempre as percepções da parte e do juiz a respeito do que é urgente coincidirão. Isso justifica, por exemplo, o indeferimento de pedidos liminares. Enquanto o jurisdicionado conhece e, em princípio, narra os fatos como ocorreram exatamente, o julgador não dispõe da mesma convicção já no limiar do processo e só é informado sobre o contexto da ação proposta ao ler o relato apresentado na petição inicial.

É inegável que todas essas constatações correspondem a uma perspectiva de urgência, a qual, por ser evidentemente particular, individual, singular, deve ser enxergada como subjetiva, porque provém das considerações internas da própria pessoa. A crítica de Carlos Augusto de Assis ${ }^{36}$ à tese jurídica do STJ no sentido de que "a experiência mostra que a parte costuma entender que sempre carece de exame urgente a questão que pretende discutir" indica que esse é realmente um dos aspectos do termo.

No entanto, reputa-se que a urgência que melhor justifica a recorribilidade das interlocutórias imprevistas por agravo de instrumento é objetiva. Quando a necessidade de reapreciação de alguma matéria preterida for realmente imediata, não somente o agravante

36 Agravo de instrumento: um olhar para o passado, uma reflexão sobre o nosso futuro. Revista Brasileira de Direito Processual-RBDPro, Belo Horizonte, ano 27, n. 106, p. 145-159, abr./jun. 2019. p. 154. 
comprová-la-á nas razões do recurso que interpuser, como também o relator no tribunal constatará, ainda que externamente à demanda e com um conhecimento menos aprofundado sobre o caso, que a questão incidental exige reexame instantâneo.

Vinícius da Silva Lemos ${ }^{37}$ explica que "não é bem a urgência subjetiva que paira na concepção de dano material ou processual da parte, mas pela ineficácia ou inutilidade futura de eventual apelação. O recorrente deve argumentar nesta linha de urgência, sem mencionar outras urgências ou pontos". Em confirmação, Cristovam Pontes de Moura e João Paulo Setti Aguiar ${ }^{38}$ advertem ser "importante esclarecer que não se trata de urgência material, [...] porquanto tal urgência está, inclusive, contemplada pelo inciso I do art. 1.015 da Lei Processual Civil". Ainda de acordo com os autores, a urgência citada pela Corte é de caráter processual ${ }^{39}$ e mantém relação direta com a utilidade do agravo de instrumento (à qual se opõe a inutilidade da apelação) para a impugnação de algumas decisões interlocutórias imprevistas.

Conclusão semelhante é concebida por William Santos Ferreira ${ }^{40}$, que identifica uma via de cabimento do agravo caracterizada exatamente pela ausência de interesse recursal da parte para, em algumas situações, impugnar decisão interlocutória ao final do

37 A decisão do tema repetitivo 988 do STJ, a taxatividade mitigada do agravo de instrumento e os seus reflexos processuais. Revista Eletrônica de Direito Processual: periódico quadrimestral da pós-graduação stricto sensu em direito processual da UERJ, Rio de Janeiro, ano 14, v. 21, n. 3, p. 639-672, set./dez. 2020. Disponível em: https://www.e-publicacoes.uerj.br/index.php/redp/article/download/48109/34899. Acesso em: 9 set. 2020. p. 661.

38 Taxatividade mitigada do agravo de instrumento interposto na fase de conhecimento e a urgência decorrente da inutilidade do julgamento em recurso diferido. Revista da Procuradoria-Geral do Estado do Acre, Rio Branco, v. 14, p. 192-230, dez. 2019. Disponível em: http://www.pge.ac.gov.br/wpcontent/uploads/2019/12/Revista2019-1.pdf\#page=192. Acesso em: 21 maio 2020. p. 219.

39 A diferenciação da urgência em material e processual também é relevante para "deixar claro que a decisão do STJ não repristina o modelo do CPC/73, como parte da doutrina vem defendendo. No sistema do Código revogado, as hipóteses de cabimento de agravo de instrumento levavam em consideração exclusivamente a urgência, tanto a decorrente da demora do processo, quanto aquela vinculada ao direito material. Sempre que houvesse risco, caberia o recurso por instrumento. O precedente do STJ, entretanto, faz referência ao periculum in mora como pericolo da infruttuosità (na famosa expressão de Calamandrei), ou seja, ao perigo causado exclusivamente pela demora do processo. O risco de dano abrangido pelo novo precedente - é importante que fique claro - não decorre da relação jurídica conflituosa, sequer é oriundo do direito material discutido pelas partes. O que provoca esse perigo é única e exclusivamente a decisão prolatada, conjugada com o decurso do tempo existente entre o momento da sua prolação e a sentença. Trata-se de um perigo que surge no processo e é exclusivamente com ele relacionado" (UZEDA, Carolina. O STJ e a taxatividade mitigada do art. 1.015 do CPC. In: FONSÊCA, Vitor. Diário processual, [s. 1.], 10 dez. 2018. Disponível em: https://diarioprocessual.com/2018/12/10/ataxatividade-mitigada-do-art-1-015-do-cpc-segundo-o-stj/. Acesso em: 25 jul. 2020).

40 Cabimento do agravo de instrumento e a ótica prospectiva da utilidade - o direito ao interesse na recorribilidade de decisões interlocutórias. Revista de Processo, São Paulo, ano 42, v. 263, p. 193-203, jan. 2017. 
processo por meio de apelação. Surge, assim, "a necessidade impondo a recorribilidade por agravo, [...] já que o aguardar o julgamento de apelação representaria tornar inútil a recorribilidade pelo momento processual que se encontrar" ${ }^{\prime 1}$.

É possível verificar, aliás, que a inutilidade do julgamento da questão no recurso de apelação, tal qual expressa na tese jurídica do STJ, é o porquê que explica o critério da urgência, de maneira que se torna necessário examinar, em relação a cada interlocutória imprevista, se todos os fundamentos da taxatividade mitigada justificam, de modo interligado e complementar, sua recorribilidade excepcional por agravo de instrumento.

Para exemplificar, reputa-se que, quando o juiz indefere pedido de decretação de tramitação sigilosa ao feito, o critério da urgência é autossuficiente para a admissão da impugnação atípica da interlocutória por agravo de instrumento, e não apenas por conta da aplicação da tese jurídica feita nos acórdãos a essa hipótese particular, mas porque o art. 189 do CPC $^{42}$ determina, sem ressalvas ou condições (à exceção do inciso IV), que os processos especificados tramitem em segredo de justiça.

Todavia, a inutilidade do recurso futuro para tutelar a hipótese de cabimento é inferida na avaliação como justificativa implícita. Vale dizer, a necessidade de reanálise do indeferimento do segredo de justiça é urgente porque a apreciação da questão simultaneamente ao julgamento da apelação já não será útil.

Outro exemplo é a tão debatida competência jurisdicional. No exame da recorribilidade excepcional da matéria, entende-se que a urgência não é apta a determinar por si só o cabimento do agravo contra a decisão interlocutória proferida. Isso porque o agravado pode argumentar (ou o próprio relator reconhecer) que, embora o juiz tenha indeferido pedido de remessa dos autos do processo àquele que é competente para apreciar

41 FERREIRA, William Santos. Cabimento do agravo de instrumento e a ótica prospectiva da utilidade - o direito ao interesse na recorribilidade de decisões interlocutórias. Revista de Processo, São Paulo, ano 42, v. 263, p. 193-203, jan. 2017. p. 197-198, grifo do autor.

42 O caput e os incisos do dispositivo preveem que "os atos processuais são públicos, todavia tramitam em segredo de justiça os processos em que o exija o interesse público ou social; que versem sobre casamento, separação de corpos, divórcio, separação, união estável, filiação, alimentos e guarda de crianças e adolescentes; em que constem dados protegidos pelo direito constitucional à intimidade; que versem sobre arbitragem, inclusive sobre cumprimento de carta arbitral, desde que a confidencialidade estipulada na arbitragem seja comprovada perante o juízo" (BRASIL. Lei no 13.105, de 16 de março de 2015. Código de processo civil. Brasília: Presidência da República, 2015. Disponível em: http://www.planalto.gov.br/ccivil_03/_ato2015-2018/2015/lei/113105.htm. Acesso em: 21 jul. 2019). 
e resolver o litígio, a anulação do feito em segunda instância em consequência da interposição de apelação ainda poderá proporcionar proveito à parte.

Nesse caso, a fim de obter uma conclusão consistente, deve-se investigar se os demais fundamentos concorrem para a demonstração de que a necessidade de reexame da questão é urgente, ou seja, é preciso que os pressupostos seguintes justifiquem de forma complementar a possibilidade de agravamento da interlocutória.

\subsection{Inutilidade do julgamento diferido da questão}

Conforme assentado na tese jurídica do STJ, a urgência do reexame de pronunciamentos incidentais imprevistos provém da inutilidade do julgamento da questão no recurso de apelação.

Segundo Fredie Didier Jr. e Leonardo Carneiro da Cunha ${ }^{43}$, a razão da recorribilidade da decisão interlocutória sobre admissão de intervenção de terceiros (inciso IX do art. 1.015 do CPC), por exemplo, é a inutilidade da faculdade de recorrer somente ao final do processo contra a já concretizada participação de interveniente, principalmente porque, se o possível apelante for o vencedor da causa, talvez a maior inconveniência suportada terá sido aguardar a extensa duração do feito em virtude da interferência do terceiro. Esse seria, portanto, um exemplo de inutilidade relativa.

Por outro lado, quando algum prejuízo é materializado em detrimento da parte e não há mecanismo propício à sua reparação ou que ainda proporcione proveito em outro instante, a inutilidade de qualquer alternativa será absoluta. O exemplo mais claro é a mencionada decisão interlocutória sobre segredo de justiça. A vulgarização da vida íntima do litigante nas situações em que o processo deva ser conduzido em sigilo, se não for coibida imediatamente, não o poderá ser em nenhuma outra oportunidade.

Assim, considera-se que a inutilidade mencionada pelo STJ na tese jurídica é absoluta. Se ao final do processo a impugnação da interlocutória prejudicial ( $\S 1^{\mathrm{o}}$ do art. 1.009 do CPC) ainda puder contribuir para a reparação satisfatória do dano, a matéria

43 Curso de direito processual civil: meios de impugnação às decisões judiciais e processo nos tribunais. 13. ed. Salvador: Editora JusPodivm, 2016. 
evidentemente não exige reapreciação imediata, o que também confirma que a inutilidade do julgamento diferido da questão define efetivamente a presença do critério da urgência.

A Rela. Mina. Nancy Andrighi ressaltou que o fundamento está associado ao princípio constitucional da inafastabilidade do controle jurisdicional, que deixou de ser enxergado unicamente pela ótica do ingresso em juízo para ser compreendido também sob a acepção do direito de recorrer oportunamente ${ }^{44}$.

Uma relação assimétrica é estabelecida entre os recursos interponíveis contra as decisões interlocutórias imprevistas, a qual também é identificada por Cristovam Pontes de Moura e João Paulo Setti Aguiar ${ }^{45}$, a saber, "utilidade do agravo de instrumento e [...] consequente inutilidade de apreciação da questão em recurso diferido", isto é, apelação.

William Santos Ferreira ${ }^{46}$ acrescenta que essa é uma circunstância implícita da recorribilidade dos pronunciamentos incidentais, cujo fundamento é o interesse recursal, dividido em utilidade e necessidade. $\mathrm{O}$ autor esclarece que a utilidade é prospectiva, ou seja, o recorrente deve considerar que a interposição imediata e excepcional do agravo de instrumento retornará melhor proveito do que a deliberação da primeira instância, e a necessidade representa a imprescindibilidade do recurso para a obtenção do provimento pretendido $^{47}$.

44 Essa perspectiva é corroborada por William Santos Ferreira, para quem "não é possível sustentar exclusivamente a apelação, isto porque é uma interpretação que inobserva a garantia estampada no inc. XXXV do art. 5. ${ }^{\circ}$ da CF/1988: 'a lei não excluirá da apreciação do Poder Judiciário lesão ou ameaça a direito'; nem afirmar que a apelação significaria acesso, pois acesso inoportuno, intempestivo, além de descumprir a cláusula pétrea indicada, ainda inobserva uma outra que é a razoável duração do processo (inc. LXXVIII do art. 5. ${ }^{\circ}$ da CF/1988), porque não há 'razoabilidade' quando no momento do julgamento não há mais condições para efetivação da decisão que for tomada" (Cabimento do agravo de instrumento e a ótica prospectiva da utilidade - o direito ao interesse na recorribilidade de decisões interlocutórias. Revista de Processo, São Paulo, ano 42, v. 263, p. 193-203, jan. 2017. p. 194, grifos do autor).

45 Taxatividade mitigada do agravo de instrumento interposto na fase de conhecimento e a urgência decorrente da inutilidade do julgamento em recurso diferido. Revista da Procuradoria-Geral do Estado do Acre, Rio Branco, v. 14, p. 192-230, dez. 2019. Disponível em: http://www.pge.ac.gov.br/wpcontent/uploads/2019/12/Revista2019-1.pdf\#page=192. Acesso em: 21 maio 2020. p. 219.

46 Cabimento do agravo de instrumento e a ótica prospectiva da utilidade - o direito ao interesse na recorribilidade de decisões interlocutórias. Revista de Processo, São Paulo, ano 42, v. 263, p. 193-203, jan. 2017.

47 Cristovam Pontes de Moura e João Paulo Setti Aguiar sustentam a mesma ideia quando afirmam que "a necessidade ou utilidade do recurso é, portanto, pressuposto para sua admissibilidade, tendo sido esse o elemento basilar utilizado pelo Superior Tribunal de Justiça para estabelecer sob quais parâmetros deve ser analisada a urgência para conhecimento de agravo de instrumento além dos casos expressamente previstos no art. 1.015 do Código de Processo Civil" (Taxatividade mitigada do agravo de instrumento interposto na fase de conhecimento e a urgência decorrente da inutilidade do julgamento em recurso diferido. Revista da Procuradoria-Geral do Estado do Acre, Rio Branco, v. 14, p. 192-230, dez. 2019. 
$\mathrm{Na}$ exposição do elemento da urgência, observou-se que a inutilidade do julgamento diferido da questão lhe serve como justificativa. O próprio enunciado da tese jurídica do STJ torna essa constatação evidente, uma vez que declara ser cabível agravo de instrumento excepcionalmente "quando verificada a urgência decorrente da inutilidade do julgamento da questão no recurso de apelação" ${ }^{\text {48 }}$. Assim, o critério que fundamenta a interposição do recurso é prioritariamente a urgência, reconhecida inclusive como "cláusula adicional de cabimento" $" 49$, mas a causa desta é a mencionada inutilidade ${ }^{50}$.

Novamente em relação à decisão sobre segredo de justiça, se a matéria da causa corresponde claramente a alguma das hipóteses previstas no art. 189 do CPC, a atribuição de sigilo processual à demanda é necessidade iminente, de forma que prescindiria de qualquer outra reflexão a análise da impugnabilidade por agravo do pronunciamento que indefere a providência. A divulgação da vida íntima da parte é, contudo, prejuízo evidentemente irreparável, razão por que nesse caso a inutilidade do julgamento diferido da questão é fundamento subentendido.

Disponível em: http://www.pge.ac.gov.br/wp-content/uploads/2019/12/Revista2019-1.pdf\#page=192. Acesso em: 21 maio 2020. p. 221-222).

48 BRASIL. Superior Tribunal de Justiça. Recurso Especial no 1.696.396 - MT (2017/0226287-4). Recurso especial representativo de controvérsia. Direito processual civil. Natureza jurídica do rol do art. 1.015 do CPC/2015. [...]. Relatora: Mina. Nancy Andrighi, 5 de dezembro de 2018. Disponível em: https://ww2.stj.jus.br/websecstj/cgi/revista/REJ.cgi/ITA?seq=1731780\&tipo=0\&nreg=201702262874\&S eqCgrmaSessao $=\&$ CodOrgaoJgdr $=\& d t=20181219 \&$ formato $=P D F \&$ salvar $=$ false. Acesso em: 22 jun. 2019. p. 58, grifo do autor.

49 BRASIL. Superior Tribunal de Justiça. Recurso Especial n ${ }^{o} 1.696 .396$ - MT (2017/0226287-4). Recurso especial representativo de controvérsia. Direito processual civil. Natureza jurídica do rol do art. 1.015 do CPC/2015. [...]. Relatora: Mina. Nancy Andrighi, 5 de dezembro de 2018. Disponível em: https://ww2.stj.jus.br/websecstj/cgi/revista/REJ.cgi/ITA?seq=1731780\&tipo=0\&nreg=201702262874\&S eqCgrmaSessao $=\&$ CodOrgaoJgdr $=\& d t=20181219 \&$ formato=PDF\&salvar=false. Acesso em: 22 jun. 2019. p. 48.

50 Essa interdependência está expressa nos acórdãos dos recursos especiais repetitivos: "Pode-se afirmar, com segurança, que a urgência que justifica o manejo imediato de uma impugnação em face de questão incidente está fundamentalmente assentada na inutilidade do julgamento diferido se a impugnação for ofertada apenas conjuntamente ao recurso contra o mérito, ao final do processo" (BRASIL. Superior Tribunal de Justiça. Recurso Especial $n^{o} 1.696 .396$ - MT (2017/0226287-4). Recurso especial representativo de controvérsia. Direito processual civil. Natureza jurídica do rol do art. 1.015 do CPC/2015. [...]. Relatora: Mina. Nancy Andrighi, 5 de dezembro de 2018. Disponível em: https://ww2.stj.jus.br/websecstj/cgi/revista/REJ.cgi/ITA?seq=1731780\&tipo=0\&nreg=201702262874\&S eqCgrmaSessao $=\&$ CodOrgaoJgdr $=\& d t=20181219 \&$ formato $=P D F \&$ salvar $=$ false. Acesso em: 22 jun. 2019. p. 41). 
De acordo com Carlos Augusto de Assis ${ }^{51}$, se for "indeferido o requerimento de segredo de justiça, correndo, portanto, o processo, sob regime de ampla publicidade, examinar essa questão depois, em sede de apelação, é realmente inútil”. A percepção do autor corresponde, assim, à compreensão de inutilidade absoluta proposta neste estudo.

Diferente é a situação das interlocutórias sobre competência. Como já dito, não salta à vista por si só a urgência de reexame do indeferimento do deslocamento dos autos do processo para o juízo competente, ainda mais porque, mesmo que o feito seja anulado em segunda instância, os atos processuais não aproveitáveis com base na instrumentalidade das formas poderão ser refeitos, o que é um benefício, embora mínimo, para a parte.

Em contraste ao exemplo anterior, Carlos Augusto de Assis ${ }^{52}$ observa que "o exame da questão da competência por ocasião da apelação é bastante inconveniente, mas não inútil". Tal inconveniência é a anteriormente denominada inutilidade relativa, visto que ainda seria possível que o apelante conseguisse alguma vantagem por meio do referido recurso, o que de certo modo impediria a interposição anômala do agravo de instrumento.

Todavia, a desvantajosa exigência de reprodução de atos processuais após o exame do apelo é razão bastante para justificar a impugnação imediata da decisão interlocutória, isso porque ainda há um fundamento seguinte ao da inutilidade do julgamento diferido da questão que precisa ser ponderado, a saber, o de que o processo caminha em marcha progressiva, na qual são inadmissíveis retrocessos e embaraços infundados e desnecessários ${ }^{53}$.

\section{PROGRESSO NA PACIFICAÇÃ̃O DOS CONFLITOS: INADMISSÃO PROSPECTIVA DA REPETIÇÃO DE ATOS PROCESSUAIS}

O terceiro fundamento da recorribilidade excepcional por agravo de instrumento não está expresso no enunciado da tese jurídica formulada pelo STJ. Ao contrário, é

51 Agravo de instrumento: um olhar para o passado, uma reflexão sobre o nosso futuro. Revista Brasileira de Direito Processual - RBDPro, Belo Horizonte, ano 27, n. 106, p. 145-159, abr./jun. 2019. p. 155.

52 Agravo de instrumento: um olhar para o passado, uma reflexão sobre o nosso futuro. Revista Brasileira de Direito Processual - RBDPro, Belo Horizonte, ano 27, n. 106, p. 145-159, abr./jun. 2019. p. 155.

53 No que diz respeito às hipóteses de cabimento dos incisos VI (exibição ou posse de documento ou coisa), VII (exclusão de litisconsorte), IX (inadmissão, apenas, de intervenção de terceiros) e XI (redistribuição do ônus da prova) do art. 1.015 do CPC, a dispendiosa repetição de atos processuais resultante da interposição de apelação é legítimo fundamento da recorribilidade imediata. 
encontrado na fundamentação do voto da Rela. Mina. Nancy Andrighi, que ressalta, porém, haver vinculação com os dois elementos anteriores: “A questão da urgência e da inutilidade futura do julgamento diferido do recurso de apelação deve ser examinada também sob a perspectiva de que o processo não pode e não deve ser um instrumento de retrocesso na pacificação dos conflitos" $"$.

A Ministra Relatora esclarece que o vocábulo processo é derivado do termo latino procedere, cujo significado está relacionado etimologicamente à noção de prosseguimento de um percurso, de maneira que eventuais involuções fazem com que seja enxergado como verdadeiro retrocesso. "Essa constatação, apesar de parecer pueril, está intimamente ligada à ideia de urgência no reexame de determinadas questões" $" 55$.

Nessa perspectiva, considera-se que a decisão interlocutória sobre competência é um dos exemplos mais elucidativos, apesar de haver outras espécies que podem ser destacadas, como a que se refere a aspectos de direito probatório, "na medida em que é pela produção da prova que a parte consegue participar do procedimento decisório e influenciar o resultado do processo" ${ }^{56}$, justificativa que já reflete de antemão o critério da urgência, porquanto é de cunho objetivo e processual.

Quando denegado pedido de deslocamento do feito ao juízo competente para o apreciar e julgar, a reanálise do pronunciamento proferido em simultaneidade com o exame da apelação pode motivar a ocorrência de involuções indevidas na marcha processual, pois a anulação ainda que apenas de alguns atos exige refazimento daqueles que não puderem ser aproveitados sob a ótica da instrumentalidade das formas.

54 BRASIL. Superior Tribunal de Justiça. Recurso Especial $n^{\circ} 1.696 .396$ - MT (2017/0226287-4). Recurso especial representativo de controvérsia. Direito processual civil. Natureza jurídica do rol do art. 1.015 do CPC/2015. [...]. Relatora: Mina. Nancy Andrighi, 5 de dezembro de 2018. Disponível em: https://ww2.stj.jus.br/websecstj/cgi/revista/REJ.cgi/ITA?seq=1731780\&tipo=0\&nreg=201702262874\&S eqCgrmaSessao $=\&$ CodOrgaoJgdr $=\& d t=20181219 \&$ formato $=P D F \&$ salvar $=$ false. Acesso em: 22 jun. 2019. p. 44.

55 BRASIL. Superior Tribunal de Justiça. Recurso Especial no 1.696.396 - MT (2017/0226287-4). Recurso especial representativo de controvérsia. Direito processual civil. Natureza jurídica do rol do art. 1.015 do CPC/2015. [...]. Relatora: Mina. Nancy Andrighi, 5 de dezembro de 2018. Disponível em: https://ww2.stj.jus.br/websecstj/cgi/revista/REJ.cgi/ITA?seq=1731780\&tipo=0\&nreg=201702262874\&S eqCgrmaSessao $=\&$ CodOrgaoJgdr $=\& d t=20181219 \&$ formato=PDF\&salvar=false. Acesso em: 22 jun. 2019. p. 44.

56 ROCHA, Felippe Borring; MIRANDA NETTO, Fernando Gama de. A recorribilidade das decisões interlocutórias sobre direito probatório. Revista Brasileira de Direito Processual - RBDPro, Belo Horizonte, ano 26, n. 101, p. 99-123, jan./mar. 2018. p. 114. 
Já em relação à decisão de indeferimento de produção de prova, Carlos Augusto de Assis $^{57}$ interpreta que, se a avaliação da admissibilidade excepcional do agravo de instrumento for condicionada unicamente ao termo inutilidade, o pronunciamento possivelmente não será impugnável de imediato. "Afinal de contas, se a prova foi indevidamente indeferida, o Tribunal, ao julgar a apelação, poderá anular a sentença proferida em razão do cerceamento de defesa" ${ }^{" 58}$.

Por isso, entende-se que, nessa situação, o juízo acerca do cabimento atípico do recurso somente se completa quando o terceiro fundamento é considerado. Uma vez que o provimento em segunda instância da produção de prova certamente provocará a realização de dispêndio adicional de trabalho no primeiro grau por conta da necessidade de renovação da instrução, é possível concluir que a hipótese é agravável ${ }^{59}$.

A comparação dessa decisão interlocutória com a previsão do inciso VI do art. 1.015 do CPC (exibição ou posse de documento ou coisa) demonstra a razoabilidade do raciocínio, visto que a imediata recorribilidade de ambas as situações é motivada pela mesma circunstância, a saber, a imprestabilidade da revisão de um pronunciamento incidental sobre elemento de prova quando a causa já tiver sido solucionada ${ }^{60}$.

57 Agravo de instrumento: um olhar para o passado, uma reflexão sobre o nosso futuro. Revista Brasileira de Direito Processual-RBDPro, Belo Horizonte, ano 27, n. 106, p. 145-159, abr./jun. 2019.

58 ASSIS, Carlos Augusto de. Agravo de instrumento: um olhar para o passado, uma reflexão sobre o nosso futuro. Revista Brasileira de Direito Processual - RBDPro, Belo Horizonte, ano 27, n. 106, p. 145-159, abr./jun. 2019. p. 156.

59 "De fato, justamente para evitar as idas e as vindas, as evoluções e as involuções, bem como para que o veículo da tutela jurisdicional seja o processo e não o retrocesso, há que se ter em mente que questões que, se porventura modificadas, impliquem regresso para o refazimento de uma parcela significativa de atos processuais deverão ser igualmente examináveis desde logo, porque, nessa perspectiva, o reexame apenas futuro, somente por ocasião do julgamento do recurso de apelação ou até mesmo do recurso especial, seria infrutífero. Dito de outra maneira: se o pronunciamento jurisdicional se exaurir de plano, gerando uma situação jurídica de difícil ou de impossível restabelecimento futuro, é imprescindível que seja a matéria reexaminada imediatamente" (BRASIL. Superior Tribunal de Justiça. Recurso Especial $n^{o}$ 1.696.396 - MT (2017/0226287-4). Recurso especial representativo de controvérsia. Direito processual civil. Natureza jurídica do rol do art. 1.015 do CPC/2015. [...]. Relatora: Mina. Nancy Andrighi, 5 de dezembro de 2018. Disponível em: https://ww2.stj.jus.br/websecstj/cgi/revista/REJ.cgi/ITA?seq=1731780\&tipo=0\&nreg=201702262874\&S eqCgrmaSessao $=\&$ CodOrgaoJgdr $=\& d t=20181219 \&$ formato $=P D F \&$ salvar=false. Acesso em: 22 jun. 2019. p. 44-45).

60 “Uma causa é ganha ou perdida em juízo em função das provas que se possam ou não produzir. No processo, as partes têm o poder de movimentar a máquina judiciária, de argumentar em prol de uma pretensão e mesmo de recorrer da sentença em caso de insucesso da demanda. Todos esses mecanismos, de nada adiantariam se não fosse assegurado à parte o efetivo direito de provar. Dispor efetivamente do direito de fazer provas num processo é sinônimo também do poder de impugnar de imediato uma decisão do juiz que inadmita a produção de determinada prova, tida pelo autor ou pelo réu como indispensável. 
Ainda um último exemplo, o qual também foi trazido na análise dos recursos especiais afetados no STJ, refere-se à decisão interlocutória sobre procedimento, seja pela especialidade deste ou em consequência de ajuste celebrado entre as partes por meio de negócio jurídico processual.

A condução inútil de litígio por procedimento distinto em razão da hipotética impossibilidade de impugnação imediata da matéria prejudicaria à parte, que, além de não poder recorrer logo, seria obrigada a participar de todos os atos processuais já ciente de que após a finalização do feito poderia conseguir sua anulação em segunda instância para que só então fossem aplicadas as técnicas compatíveis, de forma que a inconsistência dessa alternativa justifica a possibilidade de agravamento da questão ${ }^{61}$.

Em situações como as descritas, a advertência de que o processo não deve sofrer injustas regressões torna absoluta a inutilidade relativa (ou simplesmente inconveniência) da reapreciação diferida da decisão interlocutória.

A interposição excepcional do agravo de instrumento "escora-se na utilidade prospectiva do recurso e o questionamento da inobservância do regime jurídico da apelação quando a decisão interlocutória não puder ser, no futuro, objeto de um julgamento efetivo, eficiente e eficaz" ${ }^{\prime 2}$, ou seja, é necessário que os três pressupostos discutidos sejam

Eliminar essa possibilidade é enfraquecer as garantias do acesso à Justiça, da ampla defesa e do próprio devido processo legal. Por isso, um processo civil democrático não pode conviver com a ideia de que decisões indeferitórias de provas sejam inatacáveis por agravo de instrumento" (MÜLLER, Ana Cláudia Rodrigues. Do rol não taxativo do agravo de instrumento no código de processo civil de 2015. 2016. Tese (Doutorado em Direito) - Pontifícia Universidade Católica de São Paulo, São Paulo, 2016. Disponível

em: https://tede2.pucsp.br/bitstream/handle/19541/2/Ana\%20Cl\%c3\%a1udia\%20Rodrigues\%20M\%c3\%bclle r.pdf. Acesso em: 30 jun. 2019. p. 172).

61 De acordo com a Ministra Relatora, "não é razoável aguardar o exaurimento do trâmite processual desenvolvido por um procedimento diverso daquele que a lei ou as partes entenderam como apropriado para, somente na apelação ou até mesmo no recurso especial, reconhecer que o procedimento adequado não foi seguido e que, portanto, será preciso invalidar parte significativa dos atos praticados para amoldálos à estrutura procedimental prevista em lei ou desenvolvida pelas próprias partes por meio de negócio jurídico processual” (BRASIL. Superior Tribunal de Justiça. Recurso Especial $n^{o} 1.696 .396$ - MT (2017/0226287-4). Recurso especial representativo de controvérsia. Direito processual civil. Natureza jurídica do rol do art. 1.015 do CPC/2015. [...]. Relatora: Mina. Nancy Andrighi, 5 de dezembro de 2018. Disponível

em: https://ww2.stj.jus.br/websecstj/cgi/revista/REJ.cgi/ITA?seq=1731780\&tipo=0\&nreg=201702262874\&S eqCgrmaSessao $=\&$ CodOrgaoJgdr $=\& d t=20181219 \&$ formato $=P D F \&$ salvar=false. Acesso em: 22 jun. 2019. p. 46-47).

62 FERREIRA, William Santos. Cabimento do agravo de instrumento e a ótica prospectiva da utilidade - o direito ao interesse na recorribilidade de decisões interlocutórias. Revista de Processo, São Paulo, ano 42, v. 263, p. 193-203, jan. 2017. p. 201, grifo do autor. 
devidamente demonstrados em prospecção pelo agravante, a quem incumbirá fundamentar a necessidade de reexame imediato da matéria, e certificados pelo relator, que avaliará a admissibilidade da impugnação.

\section{CONCLUSÃO}

$\mathrm{O}$ argumento de que a impugnação das decisões interlocutórias obstrui o processo tem subsistido a eras e, pelo menos aparentemente, ainda é diretriz considerada na atual sistematização do agravo de instrumento. Talvez seja esse, inclusive, o motivo da modesta relação de pronunciamentos incidentais compreendida no art. 1.015 do CPC, apesar de haver hipóteses de cabimento que poderiam ser reapreciadas adequadamente em conjunto com a impugnação contra a sentença.

Contudo, enquanto alguns casos foram escolhidos pelo legislador sem nenhuma razão plenamente justificável, outros imprescindíveis deixaram de ser incluídos no rol, o que não passou despercebido. Após a entrada em vigor do CPC de 2015, a ausência de algumas situações entre as decisões interlocutórias agraváveis foi identificada, de modo que providências começaram a ser refletidas para a reparação do problema.

Levada a questão ao STJ para ser julgada pelo rito dos recursos especiais repetitivos, formulou-se tese jurídica que reconhece a mitigação da pretensa taxatividade da relação de interlocutórias recorríveis de imediato, o que implica no cabimento do agravo também contra decisões não expressas no art. 1.015 do CPC. A insegurança jurídica que decorre da incompreensão do posicionamento construído consistiu, assim, na principal justificativa da presente pesquisa, uma vez que a pendência irresoluta é suscetível de esvaziar o esforço empreendido pela Corte para atender ao reclamo da prática processual.

Utilizou-se como suporte os acórdãos dos REsp n. 1.696.396/MT e 1.704.520/MT, dos quais foram extraídas a urgência e a inutilidade do julgamento da questão no recurso de apelação como fundamentos que justificam a mitigação da taxatividade do rol de cabimento do agravo. Associados por uma relação de causa e consequência, são esses elementos que melhor auxiliarão os recorrentes a demonstrarem a possibilidade de impugnação excepcional de determinada interlocutória imprevista que exigir reexame imediato. 
Urgência é critério objetivo, já que deve ser considerado independentemente de interesses pessoais na fundamentação do agravo a ser interposto de forma atípica, assim como na posterior avaliação de admissibilidade efetuada pelo relator no tribunal. É ainda elemento de caráter processual, o que se percebe pelas hipóteses de cabimento expressas do recurso.

Ademais, com base na distinção da inutilidade em relativa e absoluta, verificou-se que o STJ faz referência à última espécie, caracterizada pela tentativa tardia de solução de alguma questão que só poderia ser resolvida adequada e satisfatoriamente no exato momento em que tenha exigido reapreciação. Se a inutilidade for representada unicamente pela inconveniência da reanálise postergada de determinado pronunciamento incidental, não será possível interpor agravo de instrumento excepcionalmente.

Exatamente por isso, entretanto, a Ministra Relatora estabeleceu como terceiro pressuposto o fundamento complementar de que o processo deve prosseguir sem sofrer involuções, principalmente se estas puderem ser enxergadas de forma prospectiva. Qualquer embaraço passível de atravancar o processo ou fazê-lo retroceder será suficiente para definir a possibilidade de agravamento atípico de decisão interlocutória imprevista.

Assim, é preciso reconhecer que a própria existência do agravo de instrumento é fundamentada no propósito de servir ao reajuste de situações que possam causar dano irreparável (ou de difícil ou incerta reparação) à parte no processo. O cabimento do recurso deve ser verificado com base na improdutividade previsível da recorribilidade diferida, circunstância que demonstra a urgência de reexame do pronunciamento incidental.

\section{REFERÊNCIAS:}

ASSIS, Carlos Augusto de. Agravo de instrumento: um olhar para o passado, uma reflexão sobre o nosso futuro. Revista Brasileira de Direito Processual - RBDPro, Belo Horizonte, ano 27, n. 106, p. 145-159, abr./jun. 2019.

BECKER, Rodrigo Frantz. O rol taxativo (?) das hipóteses de cabimento do agravo de instrumento. Publicações da Escola da AGU, Brasília, v. 9, n. 4, p. 237-252, out./dez. 2017. Disponível em: https://seer.agu.gov.br/index.php/EAGU/article/view/2020/1745. Acesso em: 21 mar. 2020. 
BRASIL. Código de processo civil e normas correlatas. 7. ed. Brasília: Senado Federal: Coordenação de Edições Técnicas, 2015.

BRASIL. Lei $n^{o}$ 13.105, de 16 de março de 2015. Código de processo civil. Brasília: Presidência da República, $2015 . \quad$ Disponível em: http://www.planalto.gov.br/ccivil_03/_ato2015-2018/2015/lei/113105.htm. Acesso em: 21 jul. 2019.

BRASIL. Superior Tribunal de Justiça. Recurso Especial $n^{o} 1.696 .396$ - $M T$ (2017/0226287-4). Recurso especial representativo de controvérsia. Direito processual civil. Natureza jurídica do rol do art. 1.015 do CPC/2015. [...]. Relatora: Mina. Nancy Andrighi, 5 de dezembro de 2018. Disponível em: https://ww2.stj.jus.br/websecstj/cgi/revista/REJ.cgi/ITA?seq=1731780\&tipo=0\&nreg= $201702262874 \&$ SeqCgrmaSessao $=\&$ CodOrgaoJgdr $=\& d t=20181219 \&$ formato $=P D F \& s$ alvar=false. Acesso em: 22 jun. 2019.

BUENO, Cassio Scarpinella. Novo código de processo civil anotado. São Paulo: Saraiva, 2015.

CÂMARA, Alexandre Freitas. O novo processo civil brasileiro. São Paulo: Editora Atlas, 2015.

DIDIER JR., Fredie; CUNHA, Leonardo Carneiro da. Curso de direito processual civil: meios de impugnação às decisões judiciais e processo nos tribunais. 13. ed. Salvador: Editora JusPodivm, 2016.

FERREIRA, William Santos. Cabimento do agravo de instrumento e a ótica prospectiva da utilidade - o direito ao interesse na recorribilidade de decisões interlocutórias. Revista de Processo, São Paulo, ano 42, v. 263, p. 193-203, jan. 2017.

GONZALEZ, Gabriel Araújo. A recorribilidade das decisões interlocutórias no código de processo civil de 2015. 2016. Dissertação (Mestrado em Direito) - Faculdade de Direito, Universidade Federal da Bahia, Salvador, 2016. Disponível em: https://repositorio.ufba.br/ri/bitstream/ri/19980/1/Gabriel\%20Ara\%C3\%BAjo\%20Gonz alez\%20$\% 20 \mathrm{~A} \% 20$ recorribilidade $\% 20$ das $\% 20$ decis $\% \mathrm{C} 3 \% \mathrm{~B} 5 \mathrm{es} \% 20$ interlocut $\% \mathrm{C} 3 \% \mathrm{~B} 3$ rias $\% 20$ no\%20CPC\%202015.pdf. Acesso em: 23 jun. 2019. 
LEMOS, Vinícius da Silva. A decisão do tema repetitivo 988 do STJ, a taxatividade mitigada do agravo de instrumento e os seus reflexos processuais. Revista Eletrônica de Direito Processual: periódico quadrimestral da pós-graduação stricto sensu em direito processual da UERJ, Rio de Janeiro, ano 14, v. 21, n. 3, p. 639-672, set./dez. 2020. Disponível em: https://www.epublicacoes.uerj.br/index.php/redp/article/download/48109/34899. Acesso em: 9 set. 2020.

LEMOS, Vinicius Silva. O agravo de instrumento e evolução no direito brasileiro. In: COSTA, Eduardo José da Fonseca et al. (coord.). História do processo. São Paulo: ABDPRO: Editora Exegese, 2018. p. 503-544.

LEVADA, Cláudio Antônio Soares. Breves anotações sobre os três anos de vigência do CPC/2015. Revista de Direito Processual Civil, Jundiaí, v. 1, n. 1, p. 6-9, jan./jun. 2019. Disponível em: http://www.portal.anchieta.br/revistas-e-livros/direito-processualcivil/pdf/artigo-direito-proc-civil-vol1-1.pdf. Acesso em: 17 abr. 2020.

LUCON, Paulo Henrique dos Santos. Evolução do agravo no sistema jurídico brasileiro: das ordenações lusitanas ao novo código de processo civil. In: SILVA, José Anchieta da (org.). O novo processo civil. São Paulo: Lex Magister Editora, 2012. p. 591-655.

MARANHÃO, Clayton. Observações sobre o rol taxativo das hipóteses de cabimento do recurso de agravo de instrumento no CPC/2015, na perspectiva da duração razoável do processo. In: CARVALHO FILHO, Antônio; SAMPAIO JUNIOR, Herval (org.). Os juízes e o novo CPC. Salvador: Editora JusPodivm, 2017. p. 337-356.

MARINONI, Luiz Guilherme; ARENHART, Sérgio Cruz; MITIDIERO, Daniel. Novo código de processo civil comentado. 3. ed. São Paulo: Editora Revista dos Tribunais, 2017.

MOURA, Cristovam Pontes de; AGUIAR, João Paulo Setti. Taxatividade mitigada do agravo de instrumento interposto na fase de conhecimento e a urgência decorrente da inutilidade do julgamento em recurso diferido. Revista da Procuradoria-Geral do Estado do Acre, Rio Branco, v. 14, p. 192-230, dez. 2019. Disponível em: http://www.pge.ac.gov.br/wp-content/uploads/2019/12/Revista2019-1.pdf\#page=192. Acesso em: 21 maio 2020. 
MÜLLER, Ana Cláudia Rodrigues. Do rol não taxativo do agravo de instrumento no código de processo civil de 2015. 2016. Tese (Doutorado em Direito) - Pontifícia Universidade Católica de São Paulo, São Paulo, 2016. Disponível em: https://tede2.pucsp.br/bitstream/handle/19541/2/Ana\%20Cl\%c3\%a1udia\%20Rodrigues \%20M\%c3\%bcller.pdf. Acesso em: 30 jun. 2019.

NEVES, Daniel Amorim Assumpção. Manual de direito processual civil. 9. ed. Salvador: Editora JusPodivm, 2017.

OLIVEIRA JUNIOR, José Galbio. Agravo de instrumento: panorama atual da natureza jurídica do rol do art. 1.015 do código de processo civil. Revista Eletrônica Organizações e Sociedade, Iturama, v. 8, n. 9, p. 140-149, jan./jun. 2019. Disponível em: http://revista.facfama.edu.br/index.php/ROS/article/download/430/347. Acesso em: 11 maio 2020.

PITTA, Fernanda Pagotto Gomes. Cabimento do agravo de instrumento no novo código de processo civil: as decisões agraváveis de instrumento. 2019. Dissertação (Mestrado em Direito) - Pontifícia Universidade Católica de São Paulo, São Paulo, 2019. Disponível em:

https://tede2.pucsp.br/bitstream/handle/22172/2/Fernanda\%20Pagotto\%20Gomes\%20P itta.pdf. Acesso em: 1 jul. 2019.

PUGLIESE, William Soares. REsp 1704520/MT - uma análise da decisão sobre o rol taxativo mitigado do agravo de instrumento. Revista Jurídica da Escola Superior de Advocacia da OAB-PR, Curitiba, ano 4, n. 1, p. 305-325, maio 2019. Disponível em: http://revistajuridica.esa.oabpr.org.br/wp-content/uploads/2019/05/revista-esa-cap12.pdf. Acesso em: 15 abr. 2020.

ROCHA, Felippe Borring; MIRANDA NETTO, Fernando Gama de. A recorribilidade das decisões interlocutórias sobre direito probatório. Revista Brasileira de Direito Processual - RBDPro, Belo Horizonte, ano 26, n. 101, p. 99-123, jan./mar. 2018.

TUCCI, José Rogério Cruz e. Ampliação do cabimento do recurso de agravo de instrumento. Revista Consultor Jurídico, São Paulo, 18 jul. 2017. Coluna Paradoxo da Corte. Disponível em: https://www.conjur.com.br/2017-jul-18/paradoxo-corteampliacao-cabimento-recurso-deagravo-instrumento. Acesso em: 23 mar. 2020. 
UZEDA, Carolina. O STJ e a taxatividade mitigada do art. 1.015 do CPC. In: FONSÊCA, Vitor. Diário processual, [s. 1.], 10 dez. 2018. Disponível em: https://diarioprocessual.com/2018/12/10/a-taxatividade-mitigada-do-art-1-015-do-cpcsegundo-o-stj/. Acesso em: 25 jul. 2020. 